\title{
ASSESSMENT OF CHLOROQUINE SINGLE DOSE TREATMENT OF MALARIA DUE TO Plasmodium vivax IN BRAZILIAN AMAZON
}

\begin{abstract}
SUMMARY
Malaria regions of the Amazon basin have been characterized by difficult access and non-compliance of the patients to treatment. In an attempt to assess the schizonticide efficacy of chloroquine in a single dose of $600 \mathrm{mg}$, the authors realized a double-blind, placebo-controlled trial in 132 outpatients with vivax malaria. Patients were distributed into two groups: group CPLA, given chloroquine $600 \mathrm{mg}$ (single dose) on the first day of treatment, and two doses of placebo on second and third days. Group CHLO, given chloroquine $600 \mathrm{mg}$ on first day and $450 \mathrm{mg}$ on second and third day. Geometric means of the parasite density during the follow-up was similar in both groups. No differences were observed in the parasitological cure between the two groups $(\mathrm{p}=0.442)$. There was clinical and parasitological efficacy in treatment of patients given a single-dose of chloroquine. This suggests that its restricted use could be indicated in remote areas of Brazilian Amazon Region, nevertheless the inadequate response of three patients indicates the need for further studies.
\end{abstract}

KEYWORDS: Vivax Malaria; Chloroquine; Treatment.

\section{INTRODUCTION}

There is a continuous search for new antimalarial drugs or new therapeutic methods that reinforce the acceptance of the drugs by the patients with malaria. The long duration and faster clinical recovery obtained in the first forty-eight hours of treatment influence significantly the decision to abandon treatment. Many authors have been investigating whether a decrease in the doses of antimalarial drugs or shorter treatment period could be as effective as those used in the standards schemes $5,22,23,24$.

In the Malaria Program of the Evandro Chagas Institute the observation that treatment was often abandoned on day 2 or 3, has motivated studies to establish regimens with the goal of decreasing the duration of treatment and consequently increasing the patients acceptance of the doses ${ }^{1,16}$. The results of those studies demonstrated that lower doses of chloroquine and primaquine led to clinical and parasitological cure, as well as the standard scheme, and such modified schemes could be indicated in certain areas of the Amazon Region.

Following those encouraging results the authors decided to extend the studies to test chloroquine at a dosage decreased to $10 \mathrm{mg} / \mathrm{kg}$ and determine whether the chloroquine still acts as an effective schizonticide up to the end of day 3 of treatment and compare the results with traditional scheme (three doses) of antimalarial treatment with the same drug.

\section{METHODS}

Area: The study was conducted in the municipal district of Belém, located in the Northeast of Pará State. Estimated population is 1,144,312 inhabitants, of whom $65 \%$ are living in the city outskirts. In 1999, 3,630 malaria cases were registered in the municipal district, with an infection rate $<5 \%$, and thus is considered to be an area of low transmission.

Procedures: A clinical, double-blind, placebo-controlled trial was performed. One hundred and thirty-two patients were included from January 1997 to August 1998 with inclusion criteria: age over 11 years; presenting a single infection by $P$. vivax with $\geq 500$ parasites $/ \mathrm{mm}^{3}$ in thick blood smears; without recent history of antimalarial drug use (preceding thirty days); no severe vomiting or diarrhea, or other factors that might decrease absorption of the drugs; consent to participate; permanence in Belém city throughout the study period. Informed consent was obtained from the patients. Pregnant and breast-feeding women were excluded.

In an attempt to assess the asexual parasitemia, blood was collected from patients by finger puncture and a thick blood smear was stained by Giemsa method. The number of parasites, per 200 white blood cells (WBCs) was estimated at a magnification of 1,000X. This procedure was carried out on days D0 (first day of treatment), D1, D2, D3, D4 and on D5 (even if the thick films were negative) and again on D7, D14,

The Ethical Committee of Evandro Chagas Institute approved this study. All participants gave informed consent for study participation.

Financial support: Small Grants Program for Research in Malaria/Pan American Health Organization/World Health Organization. Instituto Evandro Chagas.

(1) Programa de Ensaios Clínicos em Malária, Seção de Parasitologia, Instituto Evandro Chagas, Belém, Pará State, Brasil

(2) Centro de Ensino Superior do Pará (CESUPA), Belém, Pará, Brasil

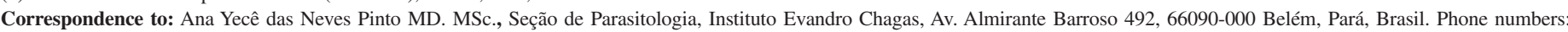
55.91.2114439, 55.91.2114466, 55.91.2114432. E-mail : ayece@iec.pa.gov.br 
D21 and D28, in agreement with recommendations of assessment studies on antimalarial drugs efficacy by World Health Organization (WHO) $)^{3,14}$.

Treatment and follow-up: The patients were randomly assigned to receive one of the therapeutic regimens in two treatment groups: chloroquine/placebo (CPLA) given $600 \mathrm{mg}$ of chloroquine on the day 1 and $450 \mathrm{mg}$ of placebo tablets on days 2 and 3, associated with $15 \mathrm{mg}$ of primaquine daily for 14 days; chloroquine/chloroquine (CHLO) given $600 \mathrm{mg}$ of chloroquine on the day $1,450 \mathrm{mg}$ of chloroquine on days 2 and 3 , associated with $15 \mathrm{mg}$ of primaquine daily for 14 days. Each tablet of chloroquine used in the study was prepared by a manipulation pharmacy in the form of a tablet, in order to obtain a homogeneous presentation of the drug.

The responses to treatment were classified by a new system, which differs from the traditional one in degrees, due to its concentration on surveillance during a short period (surveillance concentrated on days 0 , 3,7 and 14). Instead, we used an adaptation of the times and extending the study up to days 22 and $29^{14}$.

The following situations were considered:

Response A. Parasite density on D3 is above $25 \%$ compared with D0, or if this patient needed alternative antimalarial treatment on D3.

Response B. Thick blood smear positive on $\mathrm{D} 3$, with a parasite density down to $25 \%$, compared with the parasite density on D0, and which becomes positive (recrudescence of asexual parasitemia) on D7, or if this patient needs alternative antimalarial treatment on any day between D3 and D7.

Response $C$. Other situations that included patients with a positive thick blood smear but with a parasite density less than $25 \%$ compared with that of D0 and which later (until D28) became negative. This response corresponds to response type "LFT- I" (Late Failure of the Treatment).

Parasitological cure. Disappearance of asexual parasitemia by day 5 of treatment in two negative serial thick films, without evidence of recrudescence up until day 28 after beginning treatment. This corresponds to response type "ACR" (Appropriate Clinical Response).

The patients who presented relapses were treated with $600 \mathrm{mg}$ of chloroquine on the first day and $450 \mathrm{mg}$ on the second and third days, associated with $15 \mathrm{mg} / \mathrm{kg} /$ day primaquine for 14 days.
Statistical analysis: At the end of the study, the randomization code was broken and the data were included in the microcomputer database program: EPI INFO, version 6.04.

Parasitological evidence of cure was calculated by the proportion of patients with negative thick blood films on days: D4, D5, D7 and D14, compared to the total of patients included in each treatment group. Patients who could not be followed up were considered as "treatment failure" in order to avoid distortions of comparison (intention to treat) ${ }^{18}$.

The geometric mean parasite density (GMPD) was calculated taking to account the parasitemia level of the patients (evidence of clearance), excluding those considered resistant by the previous time-period evaluation. The GMPD was assessed on days D0, D1, D2, D3, D7 and D14, and compared in both groups. Fisher's exact test was used to compare proportions of patients that had cure response to the treatment, $p$ values (two-sided) less than 0.05 were considered significant.

\section{RESULTS}

One hundred and forty patients were enrolled in the study. Eight patients were excluded due to lack of follow-up or due to errors in the treatment. Thus a total of one hundred and thirty two patients were studied. After treatment codes breaking, sixty-five used treatment CHLO and sixty-seven used treatment CPLA.

Baseline data for the 132 subjects and their initial asexual parasitemia in each group are shown in Table 1.

Fever was present in $76.3 \%$ of the patients before treatment. In those patients treated with scheme CHLO, $91.2 \%$ were fever free on the fourth day of treatment, while, in the same period, $88.1 \%$ of those treated with scheme CPLA were without fever (Table 2).

During the weekly follow up, headache was a frequent symptom, and was present for more than seven days in some cases. In both groups there were reports of headache up to day 15 after beginning treatment. Among the patients of the group CPLA, only 49.2\% (29/59) had no headache up to day 4 of treatment.

The GMPD during and after treatment is shown in Figure 1. All patients showed clearance of parasitemia up to day 5 of treatment. Two patients from group CHLO and one from group CPLA presented precocious recrudescence of asexual parasitemia on the day 22 after

Table 1

Characteristics of treatment groups CHLO (standard dose) and CPLA (reduced dose)

\begin{tabular}{ccc}
\hline Characteristics & \multicolumn{2}{c}{ Treatment groups } \\
\cline { 2 - 3 } & CHLO $\mathrm{n}=65$ & $27(40.3)$ \\
\hline Female (\%) & $23(35.4 \%)$ & $40(59.7)$ \\
Male (\%) & $42(64.6 \%)$ & $31.9( \pm 16.0)$ \\
Mean age (SD)* & $29.5( \pm 11.7)$ & 47.5 \\
Mean weight (Kg) & 59 & $2,3128 / \mathrm{mm}^{3}(500-20,000)$ \\
GMDP ${ }^{\dagger}$ at day 0 (amplitude) & $1,9907 / \mathrm{mm}^{3}(500-14,000)$ & \\
\hline
\end{tabular}

* $\mathrm{SD}=$ Standard deviation; ${ }^{\dagger} \mathrm{GMPD}=$ Geometric means of parasite density at D0 


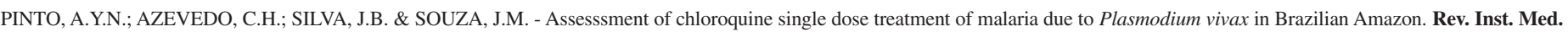
trop. S. Paulo, 45(6):327-331, 2003.

Table 2

Disappearance of signs and symptoms of malaria (fever, chills and migraine) during the week of treatment in two studied groups

\begin{tabular}{|c|c|c|c|c|c|c|c|c|c|}
\hline Signs or symptoms & & D1 & D2 & D3 & Cumulative partial (\%) & D4 & D5 & D7 & Cumulative \\
\hline \multirow[t]{2}{*}{ Fever } & CHLO & 20 & 24 & 8 & $52(91.2)$ & - & 1 & - & $53(92.0)$ \\
\hline & CPLA & 23 & 25 & 4 & $52(88.1)$ & - & - & 4 & $56(95.0)$ \\
\hline \multirow[t]{2}{*}{ Chills } & CHLO & 25 & 20 & 4 & $49(86.0)$ & 1 & 1 & 3 & $54(94.7)$ \\
\hline & CPLA & 18 & 30 & 2 & $50(94.3)$ & - & - & 2 & $52(99.0)$ \\
\hline \multirow[t]{2}{*}{ Migraine } & CHLO & 9 & 23 & 10 & $42(65.6)$ & 1 & 1 & 6 & $50(78.1)$ \\
\hline & CPLA & 10 & 15 & 4 & $29(49.2)$ & 3 & 1 & 10 & $43(72.9)$ \\
\hline
\end{tabular}

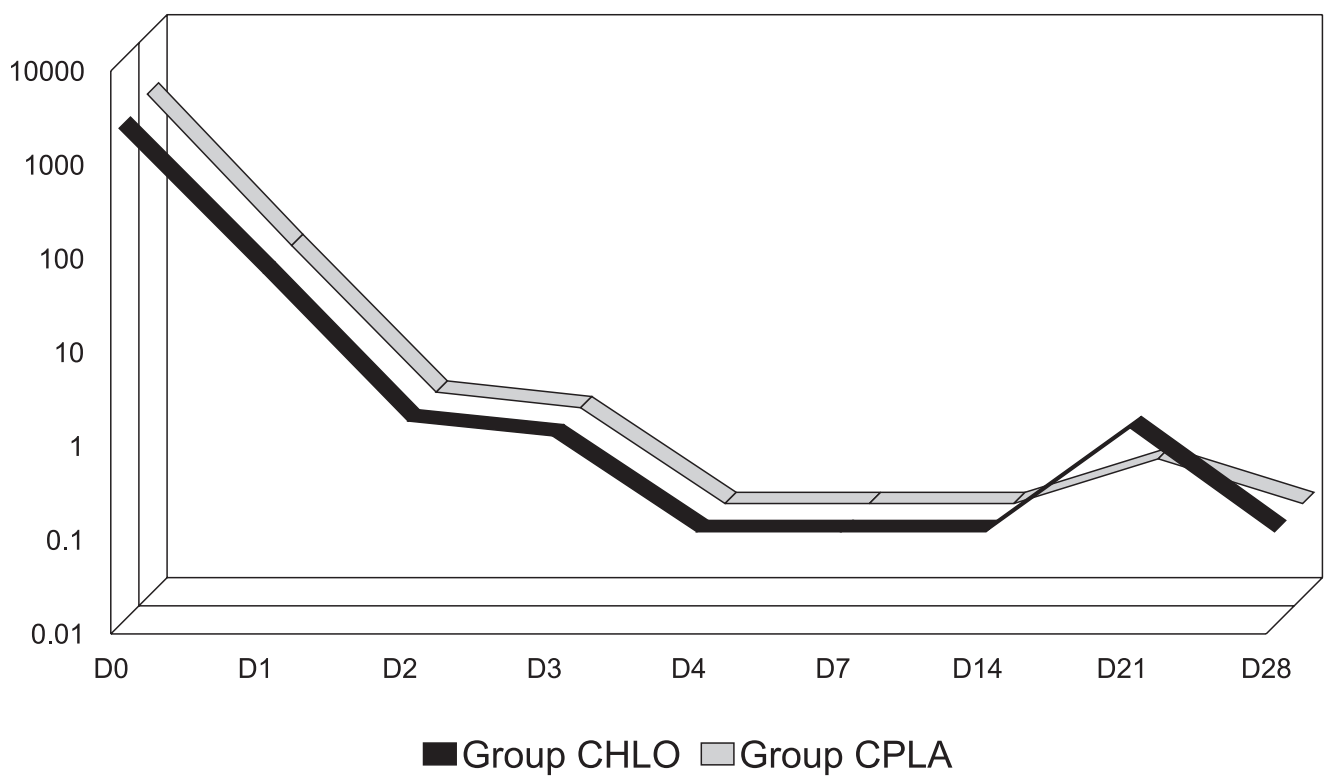

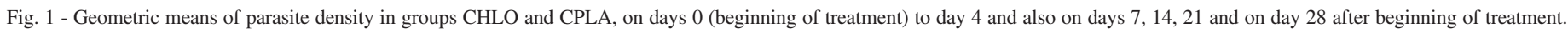

initiation of treatment. They were treated again, as indicated in Methods, and showed good response to the second treatment.

Parasitological response to treatment is shown in Table 3. Comparison of responses type A, B and C in both groups did not reveal a statistically significant difference significance $(\mathrm{p}=0.442)$.

Table 3

Therapeutic response obtained in the follow-up of patients in two studied groups

\begin{tabular}{lcc}
\hline Therapeutic response & Group CHLO & Group CPLA \\
\hline Parasitological cure & 47 & 56 \\
Response "A" & 0 & 0 \\
Response "B" & 0 & 0 \\
Response "C" & 2 & 1 \\
Indefinite* & 16 & 10 \\
\hline TOTAL & 65 & 67 \\
\hline
\end{tabular}

Fisher's Exact Test: $\mathrm{p}=0.442$; Follow-up to D21 (incomplete)
Regarding side effects of the drugs, patients from group CHLO had more pruritus, paresthesia, diarrhea, nausea and vomiting then those from group CPLA. Sweat, visual hallucinations, cyanoses and dyspnea were present in one patient from group CPLA.

\section{DISCUSSION}

The abandonment of treatment by patients with vivax malaria has been frequently reported. Consequently, the search for more useful schemes must be incessant, in an attempt to determine the probable impact upon relapses on the control programs, as a result of noncompliance.

We consider that the most useful schemes of treatment are those with a short duration or those using a small quantity of drugs. An example is the use of primaquine, the only drug that has an action against hypnozoite forms of Plasmodium vivax. Up to 1996, primaquine had been used in Brazil at $0.25 \mathrm{mg} / \mathrm{kg} /$ day over 14 days. However, in view of the prolonged treatment, this dose has been changed to a recommended dose of $0.50 \mathrm{mg} / \mathrm{kg} / \mathrm{day}$ over a shorter period of seven days ${ }^{8}$.

In the State of Pará, a serious situation of vivax malaria has prompted 
the Malaria Control Programs in Brazil to seek for more feasible schemes of treatment, in view of the difficulties that prolonged treatment imposes ${ }^{17}$. The present work has shown the effectiveness of a scheme using a single dose of chloroquine, comparable to the classical schemes. Similar results have been obtained in Asia and Africa ${ }^{6,7}$.

During the eradication campaigns in Brazil, during 1958, a so-called "presumptive dose" of chloroquine was established. This consisted of a single dose of four tablets ( $150 \mathrm{mg}$ base or $600 \mathrm{mg}$ ) of chloroquine given to the residents with fever in areas of difficult access and diagnosis. In these areas, the results of thick blood film would be available only three days after the collection of blood. Thus, improvement of symptoms and immediate prevention of transmission were ensured by the "presumptive dose" while patients waited for the result of their tests. Those patients with positive results received subsequent doses of primaquine ${ }^{13}$. There was evidence of a complete clearance of asexual parasitemia in those patients given the single dose of four tablets, and the effectiveness of chloroquine against $P$. vivax was obtained as a result of a whole-blood chloroquine concentration of approximately $90 \mu \mathrm{g} / \mathrm{mL}$. This concentration was almost always surpassed during the classic treatment with $25 \mathrm{mg} / \mathrm{kg}$ of chloroquine. The possibility of using reduced doses of chloroquine for the treatment of vivax malaria ${ }^{4,11,12}$ was emphasized.

Obviously, the first question following the decrease of antimalarial doses, is if they could induce parasite resistance. $P$. vivax resistance to chloroquine has been reported since 1989 in New Papua Guinea, Indonesia, in addition to other areas of the Asian continent ${ }^{19,20,21}$. In Brazil, there are two reports of probable chloroquine-resistance to $P$. vivax. One occurred in the State of Amazonas, where it was reported in one person with an anomalous and unique parasite response to two antimalarial drugs: chloroquine and mefloquine ${ }^{2}$. The other report occurred in the state of Rondônia, though this was possibly due to a relapse following inadequate treatment with primaquine ${ }^{9,10}$.

Theoretically, antimalarial compounds with a short half-life reduce the selectivity pressure for resistance ${ }^{25}$. Chloroquine is one of the antimalarial drugs with the longest half-life that we know. This could be the cause of fast development of resistance by $P$. falciparum to this drug and some recent evidence of decreased response of $P$. vivax to chloroquine.

The early recrudescence of asexual parasitemia (day 21) in three patients who curiously were asymptomatic or oligosymptomatic, occurred in both those using chloroquine for three days and those administered chloroquine in a single dose. This suggests an inadequate response to chloroquine that should be better studied. It is possible that carriers of vivax malaria from the Amazon region have an inadequate response to chloroquine and that this could pass undiagnosed since the standard cure controls recommended by the Fundação Nacional de Saúde [National Health Foundation] are only performed 30, 60, 90, 120, 150 and 180 days after the treatment. There is a possibility that, within a mean period of 20 days after beginning treatment, the patients present a limited parasitological recrudescence per si, without a manifest clinical picture. This phenomenon has been demonstrated by DANIEL \& MOLTA (1989). They used a single dose of chloroquine in the treatment of 53 children, in which the failure of schizonticide action of chloroquine was demonstrated and this was not associated with clinical disease ${ }^{7}$.
Three patients showing recrudescence during the follow-up, two of them had taken chloroquine for three days, suggesting that inadequate response is independent of chloroquine dose usually given.

Side effects occurred in both groups, but were much more evident in the group CHLO. The most frequent signs and symptoms were nausea and vomiting, diarrhea, pruritus, paresthesia and abdominal pain. Some of these signs and symptoms cannot be distinguished from those produced by primaquine. Pruritus and paresthesia, invariably produced by chloroquine ${ }^{15}$, were more evident in the patients from group CHLO.

We have demonstrated that a scheme using a single dose of chloroquine in the treatment of vivax malaria is as effective as the standard scheme. So, it could therefore be used in areas of difficult access in Brazilian Amazon, in an attempt to increase patient's acceptance of treatment and to resolve the problem of abandoned treatment. However, the possibility of inadequate response of $P$. vivax to this drug, shown by some other authors and suggested in the present work, indicates the need for further studies to evaluate the real impact that reduced doses of chloroquine would have in antimalarial treatment in Brazil.

\section{RESUMO}

\section{Cloroquina em dose simples no tratamento da malária por Plasmodium vivax na Amazônia brasileira}

As regiões malarígenas da Amazônia brasileira têm se caracterizado por dificuldades no acesso ao tratamento e não aceitação das drogas pelos doentes. Com objetivos de avaliar a eficácia da cloroquina em dose simples de $600 \mathrm{mg}$, os autores realizaram um ensaio clínico duplo cego, placebo controlado em 132 pacientes portadores de malária por $P$. vivax. Os pacientes foram distribuídos em dois grupos: grupo CPLA que recebia $600 \mathrm{mg}$ de cloroquina em dose simples no primeiro dia de tratamento e duas doses de placebo no segundo e terceiro dias de tratamento. Grupo CLO que recebia $600 \mathrm{mg}$ de cloroquina no primeiro dia e $450 \mathrm{mg}$ no segundo e terceiro dias. A média geométrica da densidade parasitária durante o seguimento foi similar em ambos os grupos. Não houve diferenças de cura parasitológica em ambos os grupos $(\mathrm{p}=0,442)$. Observou-se eficácia clínica e parasitológica nos indivíduos que receberam dose simples de cloroquina, indicando a possibilidade de uso restrito a algumas áreas da Amazônia brasileira, contudo, a resposta inadequada de três pacientes sugere a necessidade de outros estudos.

\section{ACKNOWLEDGEMENTS}

The authors thank Ana Lúcia Andrade and Celina Martelli from Federal University of Goiânia; Angel Valencia from Pan American Health Organization/WHO for suggestions. Special thanks are extended to Ralph Lainson and Ana Maria R. Ventura for reviewing the manuscript. To technicians Darcy da Silva Rodrigues and Orivaldo L. Mota Filho from Malaria Tests Program (Instituto Evandro Chagas).

\section{REFERENCES}

1. ABDON, N.P.; PINTO, A.Y.N.; SILVA, R.S.U. \& SOUZA, J.M. - Avaliação da resposta aos esquemas de tratamento reduzidos para malária vivax. Rev. Soc. bras. Med. trop., 34: 343-348, 2001 
2. ALECRIM, M.G.; ALECRIM, W. \& MACEDO, V. - Plasmodium vivax resistance to chloroquine (R2) and mefloquine (R3) in Brazilian Amazon region. Rev. Soc. bras. Med. trop., 32: 67-68, 1999.

3. BARAT, L.M.; HIMONGA, B.; NKUNIKA, S. et al. - A systematic approach to the development of a rational malaria treatment policy in Zambia. Trop. Med. Int. Hlth. 3: 535-542, 1998.

4. BRUCE-CHWATT, L.J., ed. - Chemotherapy of malaria. 2. ed. Geneva, WHO, 1981.

5. CLYDE, D.F. \& McCARTHY, V. - Radical cure of Chesson strain vivax malaria in man by 7, not 14, days of treatment with primaquine. Amer. J. trop. Med. Hyg, 26: 562 $563,1977$.

6. BUNNAG, D.; KARBWANG, J.; THANAVIBUL, A. et al. - High dose of primaquine in primaquine resistant vivax malaria. Trans roy. Soc. trop. Med. Hyg., 88: 218-219, 1994.

7. DANIEL, H.I. \& MOLTA, N.B. - Efficacy of chloroquine in the treatment of malaria in children under five years in Baissa (Gongola State, Nigeria). Ann. trop. Med. Parasit., 83: $331-338,1989$

8. FUNDAÇÃO NACIONAL DE SAÚDE - Manual de terapêutica da malária; colaboração de Agostinho Cruz Marques et al. Brasília, Ministério da Saúde, 2001.

9. GARAVELLI, P.L. \& CORTI, E. - Chloroquine resistance in Plasmodium vivax: the first case in Brazil. Trans. roy. Soc. trop. Med. Hyg., 86: 128, 1992.

10. LOYOLA, E.G. \& RODRIGUES, M.H. - Chloroquine resistant in Plasmodium vivax in Brazil? Trans. roy. Soc. trop. Med. Hyg., 86: 570, 1992.

11. MOST, H.; LONDON, I.M.; KANE, C.A. et al. - Landmark article July 20, 1946 : chloroquine for treatment of acute attacks of vivax malaria. J. Amer. med. Ass., 251: 2415-2419, 1984.

12. MURPHY, G.S.; BASRI, H.; PURNOMO, et al. - Vivax malaria resistant to treatment and prophylaxis with chloroquine. Lancet, 341: 96-100, 1993.

13. ORGANIZACIÓN MUNDIAL DE LA SALUD - Terminologia del paludismo y de la erradicación del paludismo. Genebra, OMS, 1964.

14. ORGANIZACION PANAMERICANA DE LA SALUD - Evaluación de la eficacia terapeutica de los medicamentos para el tratamiento del paludismo por Plasmodium falciparum sin complicaciones en las Americas. Documento adaptado por un grupo de expertos reunidos en Manaus, Brasil 1 al 5 de marzo de 1998. Manaus, OPS/ HCT/113/98, 1998.
15. OSIFO, N.G. - Chloroquine-induced pruritus among patients with malaria. Arch. Derm. 120: $80-82,1984$

16. PINTO, A.Y.N.; VENTURA, A.M.S; CALVOSA, V.P. et al. - Eficácia de quatro esquemas terapêuticos para malária vivax em crianças. J. Pediat. (Rio de J.), 74: 222-227, 1998.

17. PLANO DE INTENSIFICAÇÃO das Ações de Controle de Malária nos Estados da Amazônia Legal. [on line]. Brasília, Fundação Nacional de Saúde, 2000. Available in Web: http://www.funasa.gov.br/epi/malaria/malaria0.htm

18. POCOCK, S.J. - Protocol deviations. In: Clinical trials: a practical approach. 8. ed. Winchester, John Wiley, 1990. p. 184-193.

19. RIECKMANN, K.H.; DAVIS, D.R. \& HUTTON, D.C. - Plasmodium vivax resistance to chloroquine? Lancet, 2: 1183-1184, 1989.

20. SCHUURKAMP, G.J.; SPICER, P.E.; KEREU, R.K. \& BULUNGOL, P.K. - A mixed infection of vivax and falciparum malaria apparently resistant to 4-aminoquinoline: a case report. Trans. roy. Soc. trop. Med. Hyg., 83: 607-608, 1989.

21. SCHWARTZ, I.K.; LACKRITZ, E.M. \& PATCHEN, L.C. - Chloroquine-resistant Plasmodium vivax from Indonesia. New Engl. J. Med., 324: 927, 1991.

22. SILVA, A.R.; SILVA, C.M.P.; CARVALHO BRANCO, M.R.F. \& BRANCO FILHO, J.R.C. - Resultado do uso de um esquema terapêutico para Plasmodium vivax em cinco dias em três municípios da Ilha de São Luís, Estado do Maranhão, Brasil. Rev. Soc. bras. Med. trop., 22: 131-136, 1989.

23. SILVA, A.R.; CARNEIRO, E.W.B. \& SANTOS, H.J. - Resposta dos plasmódios humanos aos antimaláricos na Ilha de São Luís, estado do Maranhão, Brasil. Rev. Inst. Med. trop. S. Paulo, 26: 139-146, 1984.

24. SINHA, S.; DUA, V.K. \& SHARMA, V.P. - Efficacy of 5 day radical treatment of primaquine in Plasmodium vivax cases at the BHEL Industrial Complex, Hardwar (U.P). Indian J. Malar., 26: 83-86, 1989.

25. WATKINS, W.M. - Pharmacology and pharmacokinetics of new antimalarials. Med. trop., 55: 33-36, 1995.

Received: 5 December 2002

Accepted: 20 October 2003 